\title{
Idiopathic eosinophilic myositis
}

INSERM

\section{Source}

INSERM. (1999). Orphanet: an online rare disease and orphan drug data base. Idiopathic eosinophilic myositis. ORPHA:247724

Idiopathic eosinophilic myositis is a rare skeletal muscle disease characterized by eosinophilic infiltration and inflammatory lesions of the skeletal muscle tissue, in the absence of an identifiable causative factor (e.g. parasitic infection, drug intake, systemic or malignant disease). Clinically patients may present focal or generalized muscle weakness and pain, difficulties to walk, motor clumsiness and/or mild bilateral aquilae retraction, as well as elevated serum creatine kinase levels and peripheral blood and/or bone marrow hypereosinophilia. 